\title{
Influence of Information Asymmetry and Self-Efficacy on Budgetary Slack: An Experimental Study
}

\author{
Zaenal Fanani ${ }^{*}$, Georgina Elizabeth K. Saudale ${ }^{2}$ \\ 1,2 Accounting Department - Economic and Business Faculty - Universitas Airlangga \\ Jl. Airlangga No.4, Surabaya, Indonesia \\ Corresponding author; Email: "fanani@feb.unair.ac.id; elizasaudale@yahoo.com
}

\begin{abstract}
Participation in the budgetary process does not only comes with a positive effect(s) but could also lead to negative behavior(s) of employees, one of which is the creation of budgetary slack. Previous studies said that information asymmetry is rated as one of the causes of the creation of budgetary slack. The purposes of this 3x2 factorial experimental study and between subject designs are to see the effect of information asymmetry on the budgetary slack and see whether information asymmetry and self-efficacy leads to the creation of budgetary slack. This study involved 65 undergraduate and postgraduate students from the accounting department of Economics and Business Faculty in Universitas Airlangga Surabaya as participants. One way ANOVA and two- way ANOVA is used to test and analyze the proposed hypothesis. Results show that information asymmetry influences the creation of budgetary slack. However, production managers with high or low self-efficacy are still taking advantage of asymmetric information that happened to do budgetary slack.
\end{abstract}

Keywords: Information asymmetry, budgetary slack, self-efficacy, budget participation.

\section{INTRODUCTION}

In the budgetary process, the purpose of the budget itself can be aligned to the interests of an individual or a team, and behavioral problems will show when the purpose is too hard, too easy (or unclear), or when the purpose caused conflicts of interest between a company and their employee. Thus, the participation in the budgetary process resulted in several negative issues, one of which is budgetary slack. Budgetary slack is the gap between the total budget proposed by the subordinate and its best estimation [2]. Employees often have the tendency to do this when they were told to arrange the budget. Slack appears when subordinate and supervisor do not share the same interests. [13] stated that subordinates intentionally created Slack for their personal interests, even more so when budgetary achievement is used as the main indicator of performance assessment. The subordinates used this condition in the budgetary process to their advantage by lowering the budgeted revenue and raising the budgeted expenses, which caused the gap between the total budget and the company's estimation. [4] stated in his research that participation in the budgetary process tends to lower the chance of budgetary slack. A different result is found in [14], which stated that there is a positive relation between budgetary participation and budgetary slack.
The positive relation between budgetary participation and budgetary slack occured when the subordinate is involved in budgetary participation and gives inaccurate information for their own personal interests. [17] said that the high participation rate in the budgetary process gives subordinates a higher chance to do the budgetary slack. When the participation rate is low, it limits the chance to do budgetary slack and thus reduced Slack. Budgetary slack caused budget's credibility as a performance assessment tool is lowered because the allocated budget does not show the real capability of the managing subordinate. Budgetary slack will also affect next year's budgetary process.

Information asymmetry was considered as the main cause of budgetary slack [12] [13]. [12] wrote, "Local information is an example of information asymmetry, which arises when the subordinate has information relevant to the decision process associated with budgeting. Information asymmetry exists only when subordinates' information exceeds that of their superiors". In short, [12] stated that local information is an example of information asymmetry that arises when the subordinates' information on a unit of organization or subordinates' responsibility center exceeds that of their superior. [2] stated that information asymmetry came from the agency theory, where the principal gives power to their agents to manage their company or organization. 
The principal's limited information is used by the agent to do budgetary slack. Company's incentive as a form of reward to their employees' performance also spurred the subordinates to minimize the budget, so that could reach their targeted budget easily and received more incentive. This statement is supported by [11] who stated that subordinate manager will make use of information asymmetry to do budgetary slack if there are any incentives in sight.

Research on the influence of information asymmetry on budgetary slack has been done by some researchers. [23] in his/her research stated that information asymmetry has a negative influence on budgetary slack. [14] stated that information asymmetry gives negative yet significant influence on budgetary slack, that is, it could reduce the budgetary slack. This happened because the subordinates helped by giving personal information about future prospects, which produced a more accurate budget. In his/her thesis, [3] proved that information asymmetry has a positive influence toward budgetary slack. The differences in their research results may be caused by other factors that influence the relation between information asymmetry and budgetary slack.

In managing a company, employees held an important role in deciding whether the company's goal could be reached or not. Skill, attitude, and behavior of an employee became an important factor in decision making - one of them is on a budget, related to the continuity of a company. In his theory, [6] argued that human could think and manage their own behavior; so that they were not merely being a pawn, an object of environmental influence. Bandura developed self-efficacy theory, which had now become one of the psychological factors related to an individual's self, a self-recognition factors that have influences on everyday life. This is because self-efficacy influenced individuals' acts in fulfilling their goals, including future events and individual's responses when facing a problem.

Self-efficacy is an individual's faith in his/her own ability in doing their task or the action needed to reach certain goals [6]. Self-efficacy is also said as a result of the cognitive process in the form of decision, faith, or reward on how far an individual had estimated their ability in doing certain tasks or actions that were done in order to reach certain goals. Self-efficacy do not have any relation on how skillful an individual is, but on how sure that individual is on their own skill and how they have faith in their skills so that they could reach their goal and face uncertain situations. From the explanation above, it is evident that self-efficacy have an impact on an individual's actions. One of which is their performance.
[28] described that the concept of self-efficacy has impacts on an employee in dealing workplace stresses. Employees with high self-efficacy have the tendency to use the focused approach on work stress problems, on the other hand, employees with low self-efficacy have the tendency to use emotional approach.

Some relevant approaches were done with self-efficacy as the variable. One of them is [19], who tested the influence of self-efficacy on budgetary participation. He/she found that self-efficacy had a significant and positive influence on budgetary participation. [16] in his/her research also found that budgetary participation will become more effective in individuals with high self-efficacy.

A high self-efficacy on an individual will shape them into an individual who refuses to give up and full of innovations in their effort to reach the goals that they have set. Individuals will always be ready to face conditions that they have never met previously and are prepared with solutions for those problems. Meanwhile, individuals with low self-efficacy have the tendency to be distraught, depressed, and give up easily when facing problems. This is because those individuals do not have faith in their own capability.

Based on what was explained in the research backgrounds, there are two questions: 1) Do information asymmetry influence budgetary slack? 2) What are the influences of information asymmetry and self-efficacy on budgetary slack?

\section{MINDMAP}

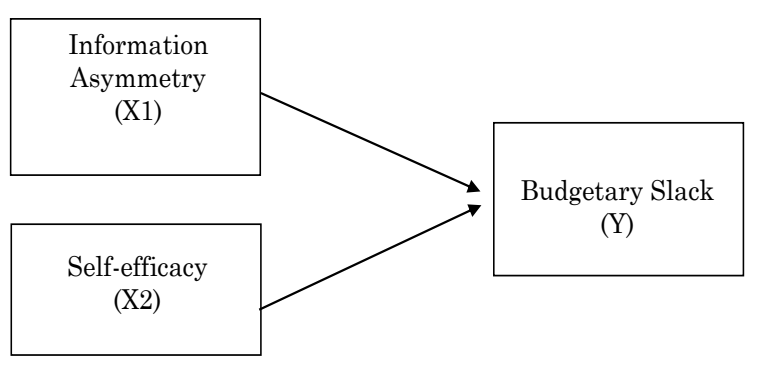

Picture 1. Mind Map

\section{Hypothesis Development}

\section{The Influence of Information Asymmetry on Budgetary Slack}

Budgetary participation has its own advantages and disadvantages. One of its advantages is that it could increase the performance of an organization. However, aside from increasing the performance, budgetary participation could also cause dysfunctional behaviors, such as budgetary slack done by an individual [26]. [12] stated that subor- 
dinate's budgetary participation gives their superior a chance to get access to local information, which enables the subordinate to show their performance that will be assessed. In reality, however, subordinates hid or held back some information that they have, thus creating budgetary slack.

Higher asymmetry information means a higher chance of budgetary slack happening. This is because the superior did not have information regarding their subordinate's performance so that the subordinates could easily manipulate the best real estimation. Subordinates will take advantage of their superior's ignorance of their real performance to create slack so that their goal could be reached and they would receive more incentives from their superior for their performance.

Some researchers focused on information asymmetry and budgetary slack, one example is [5]. Their result shows that when subordinates honestly tell their private information in the budgetary process, the company's budget efficiency will rise. [9] on their research stated that information asymmetry has a substantial impact on budgetary slack, as well as increasing it. Budgetary participation is the cause of slack, especially when there is also a high information asymmetry. [21] found that if some variables such as reputation, ethics, and self-esteem are in a high condition, it positively affects behavior that causes budgetary slack on subordinates under high information asymmetry.

A superior's lack of information is being taken advantage of by their subordinates to find bias information by doing budgetary slack. Slack itself is done by reporting an budget that is lower than what the subordinate is capable of. [24] explained that in budgetary participation, subordinate could hide some of their information, which then caused budgetary slack. From the explanations above, the researcher proposed the following research hypothesis:

H1: Information Asymmetry positively influences budgetary slack.

The Influence of Relation between Information Asymmetry and Self-Efficacy towards Budgetary Slack.

Self-efficacy is an individual's faith in their own ability in doing tasks or actions needed to reach certain goals [6]. Self-efficacy is also stated as a result of the cognitive process in the form of decision, faith, or reward on how far an individual had estimated their ability in doing a task or certain actions that were done in order to reach certain goals. Self-efficacy does not have any relation with how skillful an individual is, but on how sure that individual is with their own skills. Bandura mentioned that self-efficacy is different from aspiration because aspiration is about something ideal while self-efficacy is about self-assessment.

[28] described that the concept of self-efficacy has impacts on an employee in dealing workplace stresses. Employees with high self-efficacy have the tendency to use the focused approach on work stress problems, on the other hand, employees with low self-efficacy have the tendency to use emotional approach. [25] said individuals with high selfefficacy would do their task by considering the consequences of errors. On the other hand, individuals with low self-efficacy would feel pressure or stress from their work. Individuals with high selfefficacy considered challenges as an opportunity to display their skills [6].

[19] explained that self-efficacy has a significant and positive influence on budgetary participation. [16] also stated something similar in his research, that individual with self-efficacy would raise the effectiveness of budgetary participation. As [20] said, that budgetary participation influenced budgetary gap, then self-efficacy influenced budgetary slack through employee's participation in the budgetary process.

As explained in $\mathrm{H} 1$ about the influence of information asymmetry on budgetary slack in the context of budgetary participation, employees with high self-efficacy are expected to be able to reduce slack, because the individuals think that they are capable of accomplishing the allocated budget. Aside from that, employees with high self-efficacy are also expected to achieve their real performance without doing slack. Based on the previous explanations, the researcher proposed the following research hypothesis:

H2: Individuals with high self-efficacy do not need to do budgetary slack by taking advantage of information asymmetry in doing their work.

\section{RESEARCH METHODOLOGY}

\section{Research Design}

Research design explains all the needed processes in planning and executing the research. This research is an experimental research with $3 \times 2$ factorial and between subject design that was conducted to see the influence of information asymmetry and self-efficacy on budgetary slack, which was done by using Completely Randomized Design (CRD). Information asymmetry's variables are grouped into two conditions, high and low selfefficacy. 
Table 1. Factorial Design - Influence of Information Asymmetry and Self-efficacy on Budgetary Slack

\begin{tabular}{lccc}
\hline & $\begin{array}{c}\text { Without } \\
\text { Information } \\
\text { Asymmetry }\end{array}$ & $\begin{array}{c}\text { Medium } \\
\text { Information } \\
\text { Asymmetry }\end{array}$ & $\begin{array}{c}\text { High } \\
\text { Information } \\
\text { Asymmetry }\end{array}$ \\
\hline $\begin{array}{l}\text { Low Self- } \\
\text { efficacy }\end{array}$ & Case 1 & Case 3 & Case 5 \\
$\begin{array}{l}\text { High Self- } \\
\text { efficacy }\end{array}$ & Case 2 & Case 4 & Case 6 \\
\hline
\end{tabular}

\section{Case Experiment}

In this case experiment, the participant is seen as a low-level manager, a production manager of a plane construction company named PT Pesawat Kokoh, and the researcher is their superior. The participant is asked to do three production tasks by creating paper planes, each in two minutes. The production task 1 is considered as the production manager's past skills, the production task 2 is done to measure their expected performance. As written in [27], expected performance is the potential ability of a production's employee that could not be observed by their superior. Thus, expected performance is proxied from the average of production 1 and 2 . And production task 3 is done to see the real ability of the production manager.

Production manager will get incentives added to their basic salary as a bonus, if they could exceed the production target, and will still be given their basic salary even if they do not exceed them.

Production managers would then be grouped into three different information asymmetry. On the 'without information asymmetry' group, production managers are asked to submit all production results, 'low information asymmetry' group is only asked for production task 1 result, and high information asymmetry' group, the production manager is not asked to submit any production result.

After a production manager knows their performance, the given incentive, and the received information asymmetry condition, the manager is then asked to proposed production target to their superior. Production target proposition is a form of budgetary participation that is needed by responsibility center to support plane construction activities.

\section{Experiment Procedure}

1. Distributing research questionnaires to participants based on their information asymmetry case.

Distributing behavior questionnaire, self-efficacy questionnaire, and papers to do a production task. The questionnaire distribution is randomly done, so participants have the same probability to get a condition without information asymmetry, low information asymmetry, or high information asymmetry

2. Research explanation.

Explaining the goal and purpose of the research and steps in doing the research. The researcher will give answers to questions if there are any unclear explanation.

3. Filling the provided demographic data.

Participants are asked to fill their demographic data such as name, gender, age, major, GPA, and check the box if they have passed Management Accounting, and/or Financial and Budget Analysis (FBA) courses.

4. Doing production task 1.

Participants are asked to do production task 1 with the previously distributed papers in two minutes and fill in the production task result. Participants are not allowed to start before the instruction is given.

5. Doing production task 2.

Participants are asked to do production task 2 with the previously distributed papers in two minutes and fill in the production task result. Participants are not allowed to start before the instruction is given.

6. Doing production task 3.

Participants are asked to do production task 3 with the previously distributed papers in two minutes and fill in the production task result. Participants are not allowed to start before the instruction is given.

7. Treatment on each information asymmetry groups.

After finishing production task 1, 2, and 3, participants are then asked to read and understand the asymmetry group they belong to.

8. Deciding the target in finishing the next production task.

After participants understand the information asymmetry treatment groups from the questionnaire, they are asked to decide the production target.

9. Fill out the manipulation check Manipulation check aims to find out the participants' understanding of the case that they have received.

10. Fill out the self-efficacy questionnaire After filling out the manipulation check, participants are then asked to fill out the self-efficacy questionnaire.

\section{Operational Definition and Variable Mea- surement}

Operational definition is a definition that is given to variables by giving them meaning, activities specification, and certain operational to measure the variables [1]. In this research, three variables are used: two independent variables and one dependent variable. 


\section{Independent Variable}

Independent variable is variable that influence or causes changes to dependent variables. Independent variable is also known as treatment variable, cause, risk, stimulus variable, antecedent, influence variable, treatment, and independent variable. In this research, the researcher used independent variables, information asymmetry, and self-efficacy.

Information asymmetry is a condition where superior, as principal, does not always know the activities of low-level manager (production manager), as the agent, and the actual condition that took place in the unit that the agent was responsible for. This condition creates private information for the superior on the proposed budget. The budgetary proposal is reflected through the agent's production capability.

To distinguish the influence information asymmetry toward budgetary slack, the researcher split information asymmetry unto three groups that are measured with a nominal scale:

a. Without information asymmetry

A condition where the production manager reported all of his/her production task result to the superior so that the superior could accurately evaluate the low-level manager's performance. This condition denied the low-level manager the chance to show any kinds of underperformance. This group is identified with numeral 1.

b. Low information asymmetry

A condition where production manager only reported production task 1 to the superior. This condition caused superior to not fully understand the performance of a low-level manager, especially on production task 2 and 3 . Thus, the superior could not accurately evaluate the lowlevel manager's performance. This created a small chance for the production manager to set the production target to be lower than their real capability. This group is identified with numeral 2.

c. High information asymmetry

A condition where the production manager was not asked to report all production task result to their superior. This caused superior to know nothing of the low-level manager's performance so that the later had the chance to set the target below his/her real capability. The superior thus did not have a chance to evaluate the production target proposed by their subordinate. This group is identified with numeral 3.

In this research, all information asymmetry treatment group is given information on the incentive scheme as a payment method that will be received by production manager after doing the production task. The incentive calculation method used in this research is Fixed Pay Plus-Bonus, the same method that was used by [3] [21] [27]. The equation of the method is as written below:

$$
P=A+\left\{a x\left(Y^{\prime}-Y^{\prime}\right)\right\} \text {, if } Y^{\prime}>Y^{\prime \prime} P=A \text {, if } Y^{\prime}<Y^{\prime \prime}
$$

Notes:

$\mathrm{P}=$ Low level manager total compensation/payment

$\mathrm{A}=$ Fixed pay received by low-level manager

$\mathrm{a}=$ Bonus for each unit

$\mathrm{Y}^{\prime}=$ Actual produced output/production

$\mathrm{Y}^{\prime \prime}=$ Production target that is proposed by lowlevel manager

Self-efficacy is an individual's faith in his/her own ability in doing their task or the action needed to reach certain goals [6]. Self-efficacy do not have any relation on how skillful an individual is, but on how sure that individual is on their own skill.

To measure self-efficacy variable, the researcher used an instrument that was developed by [7] in Indonesian Adaptation of the General SelfEfficacy Scale (GSE). This instrument consists of 10 question items, which will then be measured by using Likert scale 1-5.

In this research, self-efficacy is split into two groups, high and low self-efficacy. The median of the variables is used as a cut off to determine which participants were in the high and low selfefficacy group. Participants with a total value below the median will be given number 2 as their identity.

\section{Dependent Variable}

Dependent variables are variables that received influence from independent variables. They called it the dependent variable because dependent variables are influenced by independent variables. In this research, budgetary slack is considered as the dependent variable. Budgetary slack is the gap between the total budget proposed by the subordinate and its best estimation [2]. Similar to the research done by [3] [27], this research also used the following equation:

$$
\begin{aligned}
& \begin{array}{l}
\text { Budgetary slack } \\
\text { Production Result } 3-\text { Production Target }
\end{array} \\
& \text { Expected Performance }
\end{aligned}
$$

Expected performance is the subordinate's production potential that was proxied by finding the mean of production result 1 and 2 , as written below:

$$
\begin{aligned}
& \text { Expected Performance } \\
& =\frac{\text { Production Result } 1-\text { Production Result } 2}{2}
\end{aligned}
$$




\section{RESEARCH RESULTS AND DISCUSSION}

\section{Description of the Research Subject}

This study involved college students from the Faculty of Economics and Business Universitas Airlangga Surabaya. The participants were undergraduate and postgraduate students from accounting major from the 2011 to 2015 batch, who have already passed Management Accounting and/or Financial and Budget Analysis (FBA) courses. In this experimental study, participants were seen as production manager of a plane construction company and the researcher acted as their superior.

There are 65 participants, with 22 in high information asymmetry group, 21 low information asymmetry, and another 22 grouped together in the without information asymmetry group.

\section{Validity Test}

The validity of the self-efficacy questionnaire is tested with Pearson Correlation test. This test used 0,05 significance with the two-tailed test, to get $r$ count that was tested on 30 questionnaire data.

Table 2. Pearson Correlation Test

\begin{tabular}{cccc}
\hline Question Items & Correlation Value & R Table & Status \\
\hline SE1 & 0,454 & $\geq 0,3$ & Valid \\
SE2 & 0,389 & $\geq 0,3$ & Valid \\
SE3 & 0,409 & $\geq 0,3$ & Valid \\
SE4 & 0,556 & $\geq 0,3$ & Valid \\
SE5 & 0,541 & $\geq 0,3$ & Valid \\
SE6 & 0,621 & $\geq 0,3$ & Valid \\
SE7 & 0,645 & $\geq 0,3$ & Valid \\
SE8 & 0,650 & $\geq 0,3$ & Valid \\
SE9 & 0,714 & $\geq 0,3$ & Valid \\
SE10 & 0,419 & $\geq 0,3$ & Valid \\
\hline
\end{tabular}

Source: Processed primary data, 2016

Based on table 2, the value of $r$ count is higher than $r$ table $(\geq 0,3)$, so it could be declared that the 10 question items in the self-efficacy questionnaire are valid.

After the validity test, there is a reliability test to verify the reliability of self-efficacy questionnaire. In this test, Cronbach's Alpha test is used. Questionnaire instrument will be considered as reliable when their Cronbach Alpha value is higher than $r$ table. This test used 0,05 significance with a two-tailed test on 30 data (n).

Table 3. Self-Efficacy Reliability Test

\begin{tabular}{ccc}
\hline Variable & Cronbach's Alpha & Status \\
\hline Self-Efficacy & 0,842 & Reliable \\
\hline Source: Processed primary data, 2016 &
\end{tabular}

The test result shows Cronbach's Alpha value of 0,842 , which is higher than $0,6(>0,6)$. Thus, the question items in the questionnaire are declared as reliable.

\section{Homogeneity Test}

Table 4. The Result of Chi-Square Gender Test Based on Information Asymmetry and Self-Efficacy

a. 6 cells (50\%) have expected count less than 5 . The minimum expected count is 2,91

Source: Processed primary data, 2016

Table 4 shows value of 1,174 with signification value of 0,947 which is higher than $0,05(0,947>$ $0,05)$. Thus, it could be summarized that there is no difference between gender with information asymmetry treatment group and the participant's selfefficacy. In other words, the two data samples above are of the homogenous variant.

\section{Hypothesis Test Results}

The hypothesis test on this research used one way ANOVA and two-way ANOVA tests.

The hypotheses of this research are (1) Information asymmetry positively influence budgetary slack, and (2) Individuals with high self-efficacy do not need to do budgetary slack by taking advantage of information asymmetry in doing their work.

\section{The Influence of Information Asymmetry on Budgetary Slack}

\section{a. Hypothesis Test}

To test the influence of information asymmetry on budgetary slack, the researcher used one way ANOVA test. The hypothesis is accepted if $\mathrm{F}$ count $>\mathrm{F}$ table or $\mathrm{p}$-value is more than 0,05 .

Table 5. Descriptive Statistic of Budgetary Slack's One Way ANOVA Test Based on Information Asymmetry

\begin{tabular}{lllllll}
\hline \begin{tabular}{l} 
Information \\
Asymmetry \\
\multicolumn{1}{c}{ Groups }
\end{tabular} & N & Mean & $\begin{array}{c}\text { Std. } \\
\text { Deviation }\end{array}$ & $\begin{array}{c}\text { Std. } \\
\text { Error }\end{array}$ & Min. & Max. \\
\hline High & 22 & 0,3173 & 0,21126 & 0,4504 & 0 & 0,83 \\
Low & 21 & 0,3423 & 0,23929 & 0,5222 & 0 & 0,89 \\
Without & 22 & 0,1275 & 0,37382 & 0,7970 & 0 & 1,67 \\
Total & 65 & 0,2611 & 0,29627 & 0,3675 & 0 & 1,67 \\
\hline
\end{tabular}

Source: Processed primary data, 2016

The descriptive statistic above shows that the mean of budgetary slack in a high information asymmetry is 0,3173 with standard deviation and standard error of 0,21126 and 0,4504 each. The minimum value of budgetary slack done in a high information asymmetry is 0 and the maximum 
value is 0,83 . In low information asymmetry, the mean is 0,3423 with standard deviation and standard error of 0,23929 and 0,52222 each. Minimum budgetary slack in low information asymmetry is 0 and the maximum value is 0,89 . In without information asymmetry condition, the average number of budgetary slack done by production manager is 0,1275 with standard deviation and standard error of 0,29627 and 0,03675 each. The minimum value of budgetary slack done in this condition is 0 and its maximum is 1,67 .

In this test, a test of homogeneity is also included. To test this, the researcher used Levene's Test, where the data variants are considered as homogeneous if their test result shows $p$-value $>a$ $(0,05)$.

Table 6. Variants' Homogeneity Test

\begin{tabular}{lccc}
\hline \multicolumn{1}{c}{ Variance } & $\begin{array}{c}\text { Levene's } \\
\text { Statistic }\end{array}$ & Sig. & Status \\
\hline $\begin{array}{l}\text { Budgetary slack based } \\
\text { on Information }\end{array}$ & 0,366 & 0,695 & Homogenous \\
Asymmetry & & & \\
\hline Soure: Prossed promen & & & \\
\hline
\end{tabular}

Source: Processed primary data, 2016

The result in table 6 shows that the Levene's statistic value of 0,695 , which is higher than 0,05 . Thus, the budgetary slack data based on information asymmetry is declared as homogenous.

Next, the calculation to get $\mathrm{F}$ count was done. If $p$-value $>0,05$, it can be concluded that there is no difference between treatment groups. On the other hand, if $p$-value $<0,05$, there are at least a pair of groups that received different treatment.

Table 7. Descriptive Statistic of Budgetary Slack Based on Information Asymmetry Treatment Group

\begin{tabular}{lccccc}
\hline & $\begin{array}{c}\text { Sum of } \\
\text { Square }\end{array}$ & $d f$ & $\begin{array}{c}\text { Mean } \\
\text { Square }\end{array}$ & F & Sig. \\
\hline Between Groups & 0,601 & 2 & 0,300 & 3.711 & 0,030 \\
\hline Within Groups & 5,017 & 62 & 0,081 & & \\
\hline Total & 5,618 & 64 & & & \\
\hline
\end{tabular}

Source: Processed primary data, 2016

From table 7, it is known that the p-value is 0,030 , which is lower than $\alpha=0,05(0,030<0,05)$. This shows that there is at least one pair of treatment group that is different. From here, it can be concluded that the average value of budgetary slack between information asymmetry treatment groups is significantly different, which means information asymmetry positively influence budgetary slack. H1 is thus accepted.

From the ANOVA test result, it is known that information asymmetry has an influence on the budgetary slack. The highest average of budgetary slack done by production manager is 0,3423 , which happened when the company is in a state of low information asymmetry.
To see which groups are different, there is a need to do further examination by using post hoc test [15].

Table 8. Post Hoc Test of Information Asymmetry Treatment Groups

\begin{tabular}{ccccc}
\hline $\begin{array}{c}\text { (I) Information (J) Information } \\
\text { Asymmetry } \\
\text { Groups }\end{array}$ & $\begin{array}{c}\text { Asymmetry } \\
\text { Groups }\end{array}$ & $\begin{array}{c}\text { Mean } \\
\text { Difference } \\
\text { (I-J) }\end{array}$ & $\begin{array}{c}\text { Std. } \\
\text { Error }\end{array}$ & Sig. \\
\hline \multirow{2}{*}{ High } & Low & $-0,02504$ & 0,8678 & 0,774 \\
\cline { 2 - 5 } & Without & $0,18978^{*}$ & 0,8577 & 0,031 \\
\hline \multirow{2}{*}{ Low } & High & 0,02594 & 0,8678 & 0,774 \\
\cline { 2 - 5 } & Without & $0,2482^{*}$ & 0,8678 & 0,016 \\
\hline Without & High & $-0,18978^{*}$ & 0,8577 & 0,031 \\
\cline { 2 - 5 } & Low & $-0,21482^{*}$ & 0,8678 & 0,016 \\
\hline
\end{tabular}

Source: Processed primary data, 2016

From table 8, it is known that the test that compared high information asymmetry and low information asymmetry groups resulted in p-value $=0,031<\alpha=0,05$, which make it known that there is a difference of budgetary score average between high information asymmetry and low information asymmetry treatment groups. A comparison test between low information asymmetry and without information asymmetry resulted in p-value $=0,016$ $<\alpha=0,05$, on which the conclusion is that there is a difference in budgetary slack score average between the two groups.

The highest average score differences of without information asymmetry and low information asymmetry treatment groups budgetary slack is 0,21482 . This shows that there is still a tendency for a production manager to do budgetary slack even in a condition where there is no information asymmetry.

\section{b. Coefficient of Determination $\left(R^{2}\right)$}

Coefficient of determination is used to explain the dependent variable's variation proportion or percentage that was being explained together by independent variables.

The $\mathrm{H} 1$ test is used to see whether information asymmetry has an influence on the creation of budgetary slack. H1 test method resulted in an adjusted value of $5,6 \%$

Table 9. Coefficient of Determination $\left(R^{2}\right)$ Test

\begin{tabular}{ccccc}
\hline Model & R & R square Adjusted & $\begin{array}{c}\text { Std. Error of the } \\
\text { Estimate }\end{array}$ \\
\hline 1 & 0,266 (a) & 0,71 & 0,56 & 0,28789 \\
\hline
\end{tabular}

a. Predictors: (Constant), Information Asymmetry.

Source: Processed primary data, 2016

The low percentage of coefficient of determination shows that there are other factors that affect 
budgetary slack, aside from information asymmetry, that is not being researched on this experiment.

The Influence of Relation between Information Asymmetry and Self-Efficacy on Budgetary Slack

\section{a. Hypothesis Test}

Table 10. Descriptive Statistics of Budgetary Slack Based on Information Asymmetry and Self-Efficacy

\begin{tabular}{ccccc}
\hline $\begin{array}{c}\text { Information } \\
\text { Asymmetry }\end{array}$ & $\begin{array}{c}\text { Self- } \\
\text { Efficacy }\end{array}$ & Mean & $\begin{array}{c}\text { Std. } \\
\text { Deviation }\end{array}$ & $\mathrm{N}$ \\
\hline Without & Low & 0,2749 & 0,21308 & 11 \\
Information & High & 0,3596 & 0,21066 & 11 \\
Asymmetry & Total & 0,3173 & 0,21126 & 22 \\
\hline Low Information & Low & 0,4106 & 0,25534 & 14 \\
Asymmetry & High & 0,2058 & 0,13027 & 7 \\
& Total & 0,3423 & 0,23929 & 21 \\
\hline High & Low & 0,2381 & 0,62994 & 7 \\
Information & High & 0,0759 & 0,17484 & 15 \\
asymmetry & Total & 0,1275 & 0,37382 & 22 \\
\hline Total & Low & 0,3262 & 0,35312 & 32 \\
& High & 0,1980 & 0,21542 & 33 \\
& Total & 0,2611 & 0,29627 & 65 \\
\hline
\end{tabular}

Source: Processed primary data, 2016

ANOVA two-way test measures the main effect and interaction effect of independent variables toward dependent variables. The hypothesis will be accepted if $\mathrm{F}$ count $\geq \mathrm{F}$ table or $\mathrm{p}$-value less than 0,05 , and will be rejected if $\mathrm{F}$ count $\leq \mathrm{F}$ table or $\mathrm{p}$-value more than 0,05 .

Table 10 shows the average values of budgetary slack that was done by production managers with high and low self-efficacy, which would later be tested on whether it has a significant influence on information asymmetry and self-efficacy or not. The result of the test is as table 11 .

Based on the data in table 11, the hypothesis between information asymmetry group shows $\mathrm{p}$ value $=0,143>a=0,05$. Thus, it could be concluded that there are no differences in the information asymmetry group. Hypothesis between self-efficacy group shows $p$-value $=0,202>a$ $=0,05$, so there is also no differences on self-efficacy group. Hypothesis on the interaction between information asymmetry and self-efficacy shows $\mathrm{p}$ value $=0,209<\alpha=0,05$, so it could be concluded that there is no interaction between information asymmetry and self-efficacy.

Hypothesis on the interaction between information asymmetry and self-efficacy (Information Asymmetry*Self-efficacy) shows p-value of 0,209, which is higher than $0,05(0,209>0,05)$. This fact shows that there is no interaction between information asymmetry and self-efficacy. The conclusion from two-way ANOVA testing is that the statement that says individuals with high selfefficacy do not need to do budgetary slack by taking advantage of information asymmetry condition in doing their work is rejected. Because all hypotheses tests are being rejected, there is no need to do a post hoc test.

\section{RESEARCH RESULT DISCUSSION}

\section{Influence of Information Asymmetry on Bud- getary Slack}

The $\mathrm{H} 1$ test result shows a p-value of 0,030 which is lower than $\alpha=0,05$, thus it could be asserted that there is a difference in the average value of budgetary slack. The test result proved that information asymmetry is one of the triggers of budgetary slack, it means that $\mathrm{H} 1$ is accepted.

The post hoc test result shows that the without information asymmetry and low information asymmetry group have the highest gap on the budgetary slack average: 0,21482.

As mentioned previously, the highest budgetary slack average that is done by the production manager happened in low information asymmetry condition with a value of 0,3423 and did not happen in high information asymmetry condition. This fact shows that even in the condition where

Table 11. Between-Subjects Effects Budgetary Slack Based on Information Asymmetry and Self-Efficacy Test Result

\begin{tabular}{|c|c|c|c|c|c|c|}
\hline \multicolumn{7}{|c|}{ Dependent Variable: Budgetary Slack } \\
\hline Source & $\begin{array}{c}\text { Type III Sum of } \\
\text { Squares }\end{array}$ & $\mathrm{df}$ & $\begin{array}{c}\text { Mean } \\
\text { Square }\end{array}$ & $\mathrm{F}$ & Sig. & Status \\
\hline Corrected Model & $0,961 \mathrm{a}$ & 5 & 0,192 & 2,436 & 0,045 & \\
\hline Intercept & 4,043 & 1 & 4,043 & 51,234 & 0,000 & \\
\hline Information Asymmetry & 0,317 & 2 & 0,159 & 2,011 & 0,143 & \\
\hline Self-Efficacy & 0,132 & 1 & 0,132 & 1,668 & 0,202 & \\
\hline Information Asymmetry*Self-Efficacy & 0,254 & 2 & 0,127 & 1,608 & 0,209 & $\mathrm{H} 2$ is rejected \\
\hline Error & 4,656 & 59 & 0,079 & & & \\
\hline Total & 10,050 & 65 & & & & \\
\hline Corrected Total & 5,618 & 64 & & & & \\
\hline
\end{tabular}

Source: Processed primary data, 2016 
superiors have a chance to know something or nothing about production manager's performance, they would still do budgetary slack.

Subordinate's involvement in the budgetary process is thought to be able to increase performance, unfortunately, however, their budgetary participation could cause the dysfunctional behavior to appear on individuals, for example creating budgetary slack [26]. [12] stated that the higher the participation rate, the higher their chance to directly contributing on budgetary slack.

Slack would appear when subordinates and superiors' goals are different [18]. Because there are differences in higher and lower manager's goals, the lower manager gives wrong information to their superior [2]. Subordinates deliberately creating slack because of personal interests, even more so if performance assessment is measured from budgetary achievement [10]. By giving underestimated budget goals, coupled with incomplete performance information, will make the superior create production target which is below the real performance of the subordinates. Because of that, the subordinates have no need to work hard to reach the target. Achievements will also be easier to reach. This has been proven in this research by giving incentives to production manager, which would then make them feel the need to do budgetary slack, even in a company where the principal could evaluate all production results and production manager's performances.

The result of this research is the same with [27], in which he found that information asymmetry influenced budgetary slack. [9] also agreed with the result by saying that information asymmetry's influence on budgetary slack is substantial and causes an increase of budgetary slack. Thus, it can be concluded that information asymmetry is a factor that contributes to budgetary slack's creation.

[23], however, found that information asymmetry negatively influences the relation between budgetary participation with budgetary slack. [14] in their research also stated that information asymmetry negatively, yet significantly, influence budgetary slack, that is, it could reduce budgetary slack. This happened because subordinates could be helping the company by giving private information on a future prospect so that the budget could be processed more accurately.

The Influence of Relation between Information Asymmetry and Self-Efficacy on Budgetary Slack

$\mathrm{H} 2$ test result stated that individuals with high self-efficacy do not have the need to do bud- getary slack by taking advantage of information asymmetry, or with the assumption on production manager with high self-efficacy, the influence of information asymmetry towards budgetary slack will be lower than production manager with low self-efficacy. However, the two way ANOVA test on $\mathrm{H} 2$ shows that that interaction between asymmetry and self-efficacy (Information Asymmetry ${ }^{*}$ SelfEfficacy) on budgetary slack has a p-value of 0,209 which is higher than $0,05(0,209>0,05)$.

From the calculation test, it can be concluded that there is no interaction between self-efficacy and information asymmetry with budgetary slack. Thus, the statement that says high self-efficacy individuals do not need to do budgetary slack by taking advantage of information asymmetry in doing their task is rejected (H2 is rejected).

Self-efficacy is an individual's faith in his/her own ability in doing their task or the action needed to reach certain goals. Self-efficacy is also said as a result of the cognitive process in the form of decision, faith, or reward on how far an individual had estimated their ability in doing a task or certain actions that were done in order to reach certain goals [6]. [25] said individuals with high self-efficacy would do their task by considering the consequences of errors. On the other hand, individuals with low self-efficacy would feel pressure or stress from their work. Individuals with high selfefficacy considered challenges as an opportunity to display their skills [6]. These statements caused the proposed H2 to be pulled back. Production manager with high self-efficacy in all their task will consider the production target as a chance to show their skills, and they will work hard to meet the target, even if there is a chance to do budgetary slack because of the information asymmetry.

Research results that also studied self-efficacy were done by [16] and [19]. They found that selfefficacy influence, significantly and positively, on budgetary participation. Both researchers argued that participation will be more effective for individuals with high self-efficacy. As stated by [12], the higher the participation of subordinates in the budgetary process, the higher their chance to directly contribute to the creation of budgetary slack. Information asymmetry's interaction is also found as the cause of budgetary slack [12] [13].

Information asymmetry that is supported by the superior's full ignorance on performance, is being taken advantage of by production manager to manipulate their ability so that they could reach the target and got praises from their superior for the achievement of 'conquering' the production target.

This possibility is caused by incentives by the principal. As [6] theory said, incentives as rewards 
from others as the form of appreciation to their success in doing some task(s) could affect an individual's self-efficacy. [11] also said that lower manager will take advantage of information asymmetry to do budgetary slack if the incentive is given. As a result, the received incentive would then lead to budgetary slack. Because of the incentive, production manager will always stay in their comfort zone to take advantage of low information asymmetry condition in the company to do budgetary slack for their work achievement and receive appreciation for 'conquering' all tasks and work challenge. The incentive could also raise the chance of doing budgetary slack for production managers with low self-efficacy.

\section{CONCLUSION, LIMITATION AND FUTURE RESEARCH}

\section{Conclusion}

From the series of tests done in this research, it can be concluded that (1) information asymmetry leads to budgetary slack. Budgetary slack is still done by production manager in any information asymmetry condition. This may be caused by incentives. In order to reach the goal set by their superior more easily, production manager deliberately manipulates their performance. Thus, when the superior decided the company's production target, no less than manipulation target and no more than the production manager's actual performance that is not known by the superior. As a result, the target will be easier to achieve, and huge incentives will be received by the production manager. (2) Individuals with high or low selfefficacy will take advantage of the information asymmetry condition in a company to do budgetary slack.

\section{Limitations}

Even after going through research procedures, this experiment still faced some obstacles, such as 1) there are participants that did not pass the manipulation check, though few in number, possibly because they are not reading carefully enough as there are too many questionnaire papers; 2) college students that did not have any prior experience in budgetary participation were the participants of the research sample, enabling the chance appearance of bias on the research results, which then became unable to be generalized; 3) This research did not study other variables that could affect or create budgetary slack, 4) not all experiments were done in a class, because it clashed with semester breaks, which caused only
42 out of 65 participants did the experiments inside the class, while the rest is done separately, thus prolonging the time to gather experimental data.

\section{Feedback}

Based on the research results and conclusion, there are several feedbacks: 1) make the wording in the questionnaire shorter and clearer, while also ask the participants to give their full attention when they fill out the questionnaire, 2) future researcher(s) could change participants with samples that have already been involved in actual budgetary process or have worked in a company, 3) future researcher(s) could choose other variables such as performance, work motivation, ethics, locus of control, or any other to see their influence on budgetary slack, 4) if future researcher(s) still want to use college students as research samples, experiments should be done while the semester is still on so that the experiment could be done in a classroom with a large number of samples and the data could be gathered a lot more quickly.

\section{REFERENCES}

[1] Anshori, M. \& S. Iswati, 2009. Metodologi Penelitian Kuantitatif Bahan Ajar. Surabaya: Fakultas Ekonomi Universitas Airlangga.

[2] Anthony, R.N., \& V. Govindarajan. 2005. Management Control System. USA: McGrawHill.

[3] Arthaswadaya, A. 2015. Pengaruh Asimetri Informasi Terhadap Budgetary Slack Dengan Self Esteem Sebagai Variabel Pemoderasi: Studi Eksperimen Dalam Konteks Penganggaran Partisipatif. Skripsi. Universitas Negeri Yogyakarta.

[4] Baiman, S. 1982. Agency Research in Managerial Accounting: A Survey. Journal of Accounting Literature

[5] Baiman, S., \& J. H. Evans. 1983. Pre-decision information and participative management control systems. Journal of Accounting Research, 21

[6] Bandura, A. 1994. Self-Efficacy. Encyclopedia of Human Behavior. Vol. 4: 71-81.

[7] Born, A., R. Schwarzer \& M. Jerusalem. 1995. "Indonesian Adaptation of the General SelfEfficacy Scale”. Downloaded from http://userpage.fu-berlin.de/ health/selfscal.htm, 28 December 2015.

[8] Carl S.W., J.M. Reeve \& P.E. Fess. 2005. Financial \& Managerial Accounting $8^{\text {th }}$ Edition. USA: Thomson South-Western.

[9] De Faria, D.S. 2013. The Effect of Information Asymmetry on Budget Slack: An Experimen- 
tal Research. African Journal of Business Management. Vol. 7(13): 1086-1099.

[10] Dewi, R. P. 2008. Pengaruh Budgetary Goal Characterictic Terhadap Kesenjangan Anggaran: Instansi Pemerintah Daerah Kota Padang. Skripsi. Universitas Negeri Padang.

[11] Douglas, P. C., and B. Wier. 2000. Integrating Ethical Dimensions Into a Model of Budgetary Slack. Journal of Business Ethics. Vol. 28 (3): 267-277.

[12] Dunk, Alan S. 1993. The Effect of Budget Emphasis and Information Asymmetry on The Relation Between Budgetary Slack Participation and Slack. The Accounting Review. Vol. 68(2): 400-410.

[13] Dunk, Alan S. \& Hossein Nouri. 1998. Antecedents of Budgetary Slack: A Literature Review and Synthesis. Journal of Accounting Literature. Vol. 17: 72-96.

[14] Falikhatun. 2007. Interaksi Informasi Asimetri, Budaya Organisasi, dan Group Cohesiveness dalam Hubungan Antara Partisipasi Penganggaran dan Budgetary Slack (Studi Kasus pada Rumah Sakit Umum Daerah seJawa Tengah). Simposium Nasional Akuntansi (SNA) X. Makasar (26-27 Juli 2007).

[15] Ghozali, I. 2011. Analisis Multivariate dengan Program SPSS. Edisi ke-5. Semarang: Badan Penerbitan Universitas Diponegoro.

[16] Hermastho, B. 2001. Analisis Pengaruh Variabel Struktur Organisasi, Kultur Organisasi, Locus of Control, Self-Efficacy, dan JobRelevant Information Terhadap Efektivitas Anggaran Partisipasi; Studi Konfirmasi Kinerja Manajerial pada Industri Jasa Oerbankan di Jawa Tengah. Tesis. Magister Manajemen Program Pascasarjana Universitas Diponegoro Semarang.

[17] Lukka, K. 1988. Budgetary Biasing in Organizations: Theoretical Framework and Empirical Evidence. The Accounting Review. Vol 13: 281-302.

[18] Luthan, F. 1995, "Organizational Behavior", McGraw-Hill, Inc.
[19] Mahanani, T. 2009. Pengaruh Partisipasi Anggaran Terhadap Kinerja Manajerial dengan Self Efficacy, Social Desirability, dan Organizational Commitment sebagai Variabel Intervening. Skripsi. Universitas Sebelas Maret Surakarta

[20] Merchant. K.A. 1985. Budgeting and The Propensity to Create Budgetary Slack. Accounting, Organization, and Society. Vol. 10(2): 201-210.

[21] Nugrahani, T. \& S. Sugiri, S. 2004. Pengaruh Reputasi, Etika, dan Self Esteem Suboridinat di Bawah Asimetri Informasi. Journal of Indonesian Economy \& Business. Vol. 19(4): 375-388.

[22] Nugrahani, T.S. 2006. Pengaruh Kompensasi dan Asimetri Informasi Pada Kesenjangan Anggaran. Diunduh dari http://trisiwinugrahani.blogspot.co.id tanggal 28 Desember 2015.

[23] Pello, E.V. 2014. Pengaruh Asimetri Informasi dan Locus of Control pada Hubungan Antara Penganggaran Partisipatif dengan Senjangan Anggaran. E-Jurnal Akuntansi Universitas Udayana. Vol. 6(2): 287-305.

[24] Pope, P. F. 1984. Information Asymmetries in Participative Budgeting: A Bargaining Approach. Journal of Business Finance \& Accounting. Vol 11 (Spring): 41-59.

[25] Saks, A. M. 1994. Moderating Effects of SelfEfficacy for Relationship Between Training Method and Anxiety and Stress Reactions of Newcomers. Journal of Organization Behavior. Vol 15: 639-654.

[26] Siegel, G., \& H.R. Marconi. 1989. Behavioral Accounting. USA: South-Western Publishing Co.

[27] Stevens, D.E. 2002. The Effects of Reputation and Ethics on Budgetary Slack. Journal of Management Accounting Research. Vol. 14, 153-171.

[28] Stumpf A., \& A.P. Brief. 1987. Self-efficacy Expectations and Coping With CareerRelated Events. Journal of Vocational Behavior. Vol. 31(1): 91-108. 